\title{
Na trilha sonora da História: a canção brasileira como recurso didático-pedagógico na sala de aula
}

In the soundtrack of History: the Brazilian song as a teaching resource in the classroom

Luís Guilherme Ritta Duque

\section{Resumo}

$\mathrm{O}$ artigo tem como ponto de partida a utilização da canção brasileira como recurso didático nas aulas das disciplinas de História do Brasil do curso de História da Faculdade Cenecista de Osório (Facos). O debate e as possibilidades aqui apresentados surgiram de demandas apontadas pelos alunos de graduação baseadas em alguns questionamentos básicos: como, quando e por que utilizar canções como recurso didático-pedagógico em sala de aula? As discussões e as propostas aqui reunidas tiveram como referência debates realizados em sala de aula a partir da apresentação de gravações de algumas canções brasileiras. O foco principal do artigo é, portanto, apresentar possibilidades da utilização da canção brasileira nas aulas de História, considerando uma diversidade de elementos presentes tanto nas obras musicais quanto no contexto histórico da produção das canções.

Palavras-chave: ensino de História; História do Brasil; música popular brasileira.

\begin{abstract}
This article takes as its starting point the use of Brazilian popular music as a teaching resource in History of Brazil classes in the undergraduate course of History at the Faculdade Cenecista de Osório (Facos). The debate and the possibilities presented here emerged from demands presented by undergraduate students based on some basic questions: how, when and why to use songs as a didactic-pedagogical resource in the classroom? The discussions and proposals set out here had as reference the discussions held in the classroom from the presentation of some Brazilian songs. The focus of this article is to present possibilities of using Brazilian songs in History classes, considering a variety of elements present in both musical works and in the historical context of the production of the songs.
\end{abstract}

Keywords: History teaching; History of Brazil; Brazilian popular music.

\footnotetext{
* Mestre em História pela Universidade Federal do Rio Grande do Sul (UFRGS). Professor da Faculdade Cenecista de Osório (Facos). Osório, RS, Brasil. lgduque70@gmail.com
} 


\section{Apresentando a proposta}

Este artigo tem como ponto de partida uma disposição, seguida por alguns questionamentos. A disposição, por parte dos meus alunos de graduação em História da Faculdade Cenecista de Osório, sediada em Osório, Rio Grande do Sul, em utilizar nas suas experiências de estágio em sala de aula a música como recurso didático. Dessa demanda, surgiram alguns questionamentos básicos: como, quando, por quê?

Por diversos anos, utilizei nas aulas das disciplinas de História do Brasil canções brasileiras como fonte primária, principalmente na disciplina de História do Brasil III, que tem como corte cronológico o período que vai da primeira Era Vargas até a fase posterior ao período da ditadura civil-militar iniciada em 1964. Por conta dessa prática pedagógica, fui procurado em várias oportunidades por alunos da graduação em História que buscavam sugestões para o trabalho com canções brasileiras em sala de aula, principalmente nas disciplinas de estágio.

De início, a maneira como as canções eram trabalhadas por mim era bem básica: algumas gravações eram apresentadas para ilustrar aspectos de algum período histórico debatido no decorrer do semestre, na maioria das vezes dando ênfase à letra da obra. A demanda, acompanhada pelas discussões ocorridas nas aulas, agiu no sentido de proporcionar certo refinamento na maneira como as fontes sonoras passaram a ser tratadas nas aulas de História do Brasil.

Afirmações por parte dos alunos como "Eu quero trabalhar música em sala de aula" ou "Quero trabalhar as canções de protesto", ${ }^{1}$ sem uma ideia clara de metodologia ou, por vezes, sem um conhecimento maior das fontes sonoras utilizáveis e de como utilizar essas fontes, acabaram por gerar um impulso no sentido de, além de pensar maneiras de trabalhar as canções, estimular a leitura e o debate de obras que tratassem da metodologia do ensino de História, com ênfase na utilização da música como recurso didático-pedagógico.

Em linhas gerais, com base nessa demanda apresentada pelos alunos se constituiu um debate sobre os possíveis caminhos a serem tomados a partir da disposição de utilizar a música como recurso didático-pedagógico, no sentido de ir além de apresentar as obras para ilustrar um período trabalhado e buscar a melhor maneira de levar a canção brasileira à sala de aula. 
A proposta deste artigo é, com base em alguns exemplos e sugestões, apresentar perspectivas mais amplas da utilização da canção brasileira nas aulas de História, considerando as obras nos seus mais diversos aspectos, tais como referências histórico-culturais, público, tecnologia disponível, as diferentes versões, a circulação possível e seus reflexos, assim como os diferentes estilos, ritmos e tendências. Em linhas gerais, este trabalho visa discutir possibilidades pedagógicas do uso da canção brasileira como recurso didático na sala de aula, assim como apresentar algumas sugestões de atividades a serem desenvolvidas com alunos do ensino básico e superior.

\section{PENSANDO AS POSSIBILIDADES DA \\ CANÇÃO BRASILEIRA NA SALA DE AULA}

Como ponto de partida para a discussão, apresento uma questão: de que forma a canção brasileira pode ter um papel importante nas aulas de História? Alguns elementos devem ser considerados para dar conta desse questionamento.

Em primeiro lugar, é importante afirmar que a canção, como toda manifestação cultural, é uma referência da maneira de pensar, agir e falar de determinado tempo ou lugar. Ela sofre influências dos mais variados tipos e cria modismos, como também pode ser levada a seguir certos estilos em voga. A canção consiste em verdadeiro retrato de época. Pode ser considerada uma preciosa fonte primária, passível de ser utilizada não só na pesquisa histórica, mas também como recurso pedagógico em sala de aula.

No que diz respeito à tradição cultural brasileira, a música de modo geral tem peso muito importante, estabelecendo-se ao longo dos tempos na mais significativa forma de manifestação cultural do país, muito mais popular, por exemplo, do que a literatura. Reforçando esse aspecto, devemos considerar que até meados do século passado a maior parte da população brasileira era composta de analfabetos. Como podemos ver em Fausto (2000, p.543), “segundo os dados do censo de 1950, 53,9\% dos homens e 60,6\% das mulheres eram analfabetos. Essas porcentagens caíram respectivamente para $34,9 \%$ e $35,2 \%$, de acordo com o censo de 1980". Tal realidade educacional certamente contribuiu para que a música tivesse maior destaque entre as manifestações culturais do nosso país. 
Nesse sentido, é extremamente importante pensar o uso das canções como forma de utilização de fontes históricas em sala de aula. Ao trabalharmos esse tipo de fonte, possibilitamos ao aluno uma noção mais diversificada do que é uma fonte histórica, oportunizando um aprimoramento da percepção de onde as informações sobre o passado podem ser acessadas, considerando principalmente que para o senso comum dos alunos de ensino básico, em especial aqueles que pela primeira vez têm contato com o ensino de História, a fonte escrita aparece como a única fonte de informações sobre tempos já vividos. Nessa perspectiva, a utilização das canções em sala de aula pode servir como maneira de ampliar a concepção dos alunos sobre o que é e o que pode ser uma fonte histórica.

Porém, devemos ter o cuidado de evitar a utilização das fontes históricas, sejam elas sonoras ou não, como pura e simples forma de levar aos alunos uma visualização do passado para dentro da sala de aula. É imprescindível que o documento trabalhado seja analisado nos seus diferentes aspectos e não utilizado como uma espécie de prova do que aconteceu. Como afirmam Pereira e Seffner (2008, p.126), “o uso de fontes históricas deve servir para suspender o caráter de prova que os documentos assumem desde a história tradicional e mostrar às novas gerações a complexidade da construção do conhecimento histórico".

Sendo assim, as fontes históricas utilizadas em sala de aula devem ser pensadas como algo além de uma curiosidade apresentada aos alunos, inserida nas aulas como uma maneira de ilustrar determinado momento do passado; devem ser vistas como documentos passíveis de análise e crítica.

Segundo, mais uma vez, Pereira e Seffner,

Desconfiar da fonte não quer dizer atestar sua falsidade, mas olhá-la como um monumento que as sucessivas gerações classificaram, ordenaram e ressignificaram. Desse modo, o uso de fontes em sala de aula é profícuo, na medida em que apresenta às novas gerações a complexidade da construção do conhecimento histórico e tira do documento o caráter de prova, desloca o estudante da noção de verdade que utiliza no cotidiano e, sobretudo, permite abordar o relato histórico como uma interpretação. (Pereira e Seffner, 2008, p.127)

Em se pensando no trabalho com canções em sala de aula, não podemos deixar de considerar a interação que crianças e adolescentes estabelecem nos 
dias de hoje com a música. Por intermédio de programas de computador, aplicativos de smartphones ou simplesmente utilizando-se do velho e bom rádio, os jovens de hoje têm acesso a uma enorme produção musical, tanto em diversidade quanto em quantidade. A música pode ser uma companheira constante, considerando-se as várias possibilidades apresentadas pelos já citados smartphones, graças aos seus recursos de som e vídeo, além do acesso à internet.

$\mathrm{Na}$ atividade em sala de aula, devemos levar em conta que existe uma grande possibilidade de haver diferenças significativas entre o que é ouvido pelos alunos e o que é do conhecimento (ou mesmo do gosto) dos professores no que diz respeito a estilos musicais. Nesse sentido, cabe o investimento em um processo de aproximação entre o que os educandos usualmente ouvem, o que os professores podem trazer, e aquilo que pode ser utilizado como fonte primária em sala de aula. Tal exercício inicial pode envolver temáticas, estilos, ritmos ou qualquer outro aspecto de uma canção que pode servir de elo entre a realidade do aluno e o tipo de fonte sonora trabalhada pelo professor. O mais importante nesse tipo de prática é estabelecer um exercício de diálogo, construindo em conjunto uma atividade que envolva música e História pelo entendimento das diferenças. Conforme Abud:

Música é linguagem. Assim, devemos expor o jovem à linguagem musical de forma a criar um espaço de diálogo a respeito de música e por meio dela. Como acontece com qualquer outra linguagem, cada povo, grupo social ou indivíduo tem sua expressão musical. Portanto, cabe ao professor, antes de transmitir sua própria cultura musical (no caso, relacionada ao conhecimento histórico), pesquisar o universo musical ao qual o jovem pertence e, daí, encorajar atividades relacionadas com a descoberta e construção de novas formas de conhecimento por meio da música. (Abud; Silva; Alves, 2010, p.61)

Algumas obras que têm como foco o ensino de História tratam, dentro de um conjunto de propostas metodológicas mais amplas, da utilização da música na sala de aula, mas essencialmente focam as suas análises e propostas na utilização das letras. Como exemplos dessas obras, podemos citar Bittencourt (2008), Guimarães (2003) e Abud (2010).

Ainda que as letras das canções sejam elemento importante na análise de um documento sonoro levado aos alunos, é necessário salientar que ao trabalharmos com a canção brasileira nas aulas de História é essencial também 
refletir sobre outros aspectos das obras utilizadas. Nesse sentido, devemos considerar como elemento de análise os diferentes aspectos apresentados pelas canções. De acordo com Marcos Napolitano, “o pesquisador deve levar em conta a estrutura geral da canção, que envolve elementos de natureza diversa e que devem ser articulados ao longo da análise” (Napolitano, 2004, p.78). O mesmo autor divide inicialmente tais elementos em parâmetros verbopoéticos e parâmetros musicais. O primeiro envolve "os motivos, as categorias simbólicas, as figuras de linguagem, os procedimentos poéticos" (Napolitano, 2004, p.79); o segundo trata de "criação (harmonia, melodia e ritmo) e interpretação (arranjo, coloração timbrística, vocalização etc.)". Aliado a isso, devem ser considerados no trabalho de sala de aula outros elementos, como o contexto histórico em que a obra foi produzida, as referências/influências do autor e/ ou do intérprete, o contexto tecnológico em que a obra foi produzida, assim como outros aspectos que terão influência na estrutura da canção analisada.

Ainda sobre a diversidade de elementos que uma canção pode oferecer, propõe Paranhos:

Quando não permanecemos reféns da mera literalidade das letras das canções, aí sim estamos aptos a perceber que o significante não se acha irremediavelmente comprometido com um significado único, esvaziado de historicidade. Na perspectiva aqui adotada, uma canção está longe de reter um sentido fixo, pré-fabricado ou predeterminado. Afinal, examinada dialeticamente, a produção de sentidos, como parte de uma espécie de jogo polissêmico, abriga múltiplas leituras possíveis, por mais ambíguas e contraditórias que sejam. O sim pode transmutar-se em não, e vice-versa, ou em talvez. (Paranhos, 2006, p.4830)

Mais recentemente, em obra que tem como foco a utilização da canção brasileira no ensino de História, Hermeto (2012) buscou ampliar a análise da utilização da canção como instrumento didático. A autora trabalha como ponto de partida importantes questões teórico-metodológicas que envolvem as atividades com canções nas aulas de História. Além disso, busca, entre outras coisas, ressaltar uma série de aspectos importantes, como, por exemplo, o contexto histórico em que foi produzida a obra e a análise da performance dos intérpretes. Na obra aqui citada, a autora propõe várias atividades envolvendo as canções para o trabalho em sala de aula. 
A partir do que foi exposto, serão apresentadas neste texto algumas canções, dispostas em quatro blocos. O critério utilizado não visa estabelecer uma cronologia da música popular brasileira, mas sim apresentar sugestões e discutir formas de como trabalhar esse tipo de documento histórico nas aulas de História.

Ressalto que optei por não disponibilizar as letras das canções citadas neste artigo, uma vez que elas podem ser facilmente acessadas em sites da internet como letras.mus.br ou vagalume.com.br. As canções aqui citadas e as suas diferentes versões podem ser acessadas no site Youtube.com.

Como critério para a escolha dos blocos aqui apresentados, assim como das canções que deles fazem parte, utilizei as seguintes referências:

- o uso da canção como recurso pedagógico;

- o papel da canção brasileira como documento histórico;

- a análise da canção como um todo (referências histórico-culturais, público, tecnologia disponível, as diferentes versões e/ou interpretações, a circulação possível e seus reflexos).

\section{Apresentando PROPOSTAS DE ATIVIDADE}

No primeiro bloco, apresento três canções que, além de serem produzidas no Brasil e terem a letra em português, pouco mais têm em comum. A proposta aqui é mostrar aos alunos como a noção da passagem do tempo pode ser notada a partir das audições de alguns registros sonoros.

As canções selecionadas são Isto é bom, composta no final do século XIX por Xisto Bahia, na versão interpretada pelo cantor Bahiano (uma das primeiras gravações feitas no Brasil, em 1902), À procura da batida perfeita (2003), de Marcelo D2, interpretada pelo autor, e Chega de saudade (1958), de Tom Jobim e Vinicius de Moraes, interpretada por João Gilberto.

Essas diferentes canções, gravadas em épocas bastante distintas, podem servir de ilustração dos efeitos dos recursos tecnológicos disponíveis, ou da limitação desses recursos, na forma em que a canção é registrada.

Gravada no sistema mecânico, Isto é bom fazia o seu intérprete, Bahiano, ter de praticamente gritar para que sua voz pudesse ser registrada com algum sucesso. Evidentemente, a menor sensibilidade da gravação mecânica, se 
comparada com a gravação eletromagnética, utilizada a partir da década de 1920, acaba por ter significativa influência na maneira como a obra é interpretada.

Chega de saudade é considerada como o ponto de partida da bossa nova. A versão citada aqui não é a primeira da obra; a canção foi gravada inicialmente por Elizeth Cardoso, no disco Canção do Amor Demais, 6 meses antes do registro de João Gilberto, no mesmo ano de 1958. Ocorre que, na versão de João Gilberto, três características-chave da bossa nova se encontram: a letra de Vinicius de Moraes, a música de Tom Jobim e a interpretação de João Gilberto, tanto na maneira de cantar quanto na batida do violão.

À procura da batida perfeita é uma canção do segundo disco solo de Marcelo D2. Na obra, o artista trabalha com uma mistura de ritmos e estilos, nacionais e estrangeiros (como o $\mathrm{rap}^{2}$ e o samba). Outro elemento interessante presente na obra é a farta utilização de equipamentos eletrônicos.

Considerando as três canções aqui citadas, algumas questões podem ser apresentadas aos alunos para o debate em sala de aula: João Gilberto poderia interpretar Chega de Saudade como foi gravada em 1958, no seu estilo de interpretação intimista, característico da bossa nova, com os recursos tecnológicos disponíveis na primeira década do século XX, época em que foi gravada Isto é bom? Seria possível realizar a gravação de À procura da batida perfeita da mesma maneira como foi registrada na primeira década no século XXI nos anos 1950, época em que gravações estereofônicas davam os seus primeiros passos e a utilização de sintetizadores não era nem um sonho distante? É possível notar, após a audição das três canções, qual registro parece ser mais recente e qual seria o mais antigo? A tecnologia disponível em determinada época é um importante elemento a ser observado e debatido nas atividades com canções na sala de aula. Tal aspecto pode ter efeito significativo na produção musical de um período histórico.

Acredito que este primeiro bloco possa ser apresentado aos alunos como uma espécie de abertura dos trabalhos para as atividades com canções na sala de aula. Como foi apresentado a partir dos questionamentos presentes no parágrafo anterior, nesse período de mais de cem anos de diferença entre a primeira e a terceira gravação é possível perceber a passagem do tempo de várias maneiras, como, por exemplo, pela performance dos intérpretes, pelos equipamentos 
utilizados nos registros (como os instrumentos musicais ou os recursos de gravação) ou mesmo pela qualidade apresentada nas gravações.

O segundo bloco se baseia num corte cronológico que tem como referência o ano de 1970. A ideia aqui apresentada surgiu de uma conversa com um aluno do curso de graduação em História da Facos, durante o intervalo de uma aula. O aluno me abordou em um dos corredores da faculdade apresentando esta situação: "Quero trabalhar com a música da ditadura militar". A partir disso, comecei uma troca de ideias com ele a fim de dar um rumo mais claro para a proposta. Como ponto de partida, coloquei questões básicas: Como? Por quê? Com quais canções? A ideia do aluno era trabalhar a resistência à ditadura militar, mas de fato a produção musical brasileira do período foi composta apenas por canções de resistência?

Para esse segundo bloco, o ano de 1970 foi utilizado por conta da sua complexidade histórica. Ao mesmo tempo que o Brasil vivenciava um surto ufanista patrocinado pelo governo militar, reforçado pelo chamado boom do "milagre econômico brasileiro" e pelo título mundial de futebol, conquistado na Copa do Mundo do México, ocorria um dos momentos mais duros da ditadura militar que controlou o país por mais de 20 anos, com uma violenta escalada de repressão a qualquer movimento contestatório.

Com três diferentes canções, podemos buscar um panorama possível sobre a recepção da sociedade da época em relação ao momento histórico vivido pelo Brasil. O samba Apesar de você, de Chico Buarque, interpretado pelo autor, com letra que de forma irônica questiona a autoridade do general-presidente Emílio Médici, pode ser visto como um bom exemplo de manifestação contra o regime, a resposta daqueles que não aceitavam se enquadrar nas normas impostas pela ditadura e que, por conta disso, muitas vezes pagavam por sua rebeldia, como aconteceu com o próprio Chico Buarque, sistematicamente censurado até optar pelo exílio. A canção Eu te amo meu Brasil, da dupla Don e Ravel, interpretada pelos autores, com forte ênfase nacionalista, estabelece um contraponto em relação à primeira obra, apontando para a parte da população cooptada por esse mesmo regime, com sua letra que exalta de forma acrítica o Brasil, sem questionar o conjunto de arbitrariedades patrocinado pelos militares. Já o sucesso do xote ${ }^{3}$ Procurando tu, de Antônio Barros e J. Luna, interpretado pelo Trio Nordestino, com ritmo dançante e letra maliciosa, dá uma ideia de que de alguma maneira parte da população brasileira podia 
não apoiar o regime vigente, mas talvez não se sentisse significativamente atingida pelo fato de o país viver sob uma ditadura militar.

Tudo isso pode ser pensado com base na receptividade das três canções, se considerarmos os quase cem mil discos (em formato de compacto) vendidos de Apesar de você, antes de o governo militar proibir a canção; o sucesso de Eu te amo meu Brasil nos desfiles de Sete de Setembro na década de 1970, ou a dimensão nacional que teve Procurando tu, que, ainda que fosse uma canção com características tipicamente regionais, um xote, que a princípio teria na região Nordeste o seu foco de aceitação, acabou rivalizando com as canções de Roberto Carlos nas paradas de sucesso do ano em que foi lançada. O país era controlado por um regime de exceção, mas poderia haver diferentes juízos em relação a isso. O sucesso dessas três canções pode nos informar algo sobre tal aspecto.

Considerando o estudo da conjuntura histórica da época, as canções citadas neste bloco podem ser trabalhadas a partir de questões básicas: do que tratam essas canções? O que elas têm em comum? De que forma sofrem influência do momento histórico em que foram produzidas? A ideia é debater com os alunos como um determinado momento histórico pode ter leituras diferentes (no caso da ditadura civil-militar brasileira, apoio, contestação ou mesmo indiferença), e como a produção musical da época pode ser uma fonte interessante para nos dar acesso a essa leitura.

O terceiro bloco deste artigo é uma espécie de desdobramento do bloco anterior. A proposta aqui apresentada tem origem no mesmo diálogo com o aluno anteriormente mencionado. Como já citado, ele pretendia trabalhar "canção de protesto durante a ditadura". A partir disso, surgiram alguns questionamentos: Qual "canção de protesto"? A canção brasileira serviu como um veículo de protesto apenas no período da ditadura? Considerando tais questões, escolhi três obras de diferentes épocas e diferentes momentos históricos do Brasil. As canções selecionadas para este bloco são O trem atrasou (1941), de Pasqualito, Estanislau Silva e Paquito, interpretada por Roberto Paiva; Roda viva (1967), composta e interpretada por Chico Buarque, e Desempregado (1985), de Podrão, Mila, Bosco e Cascão, interpretada pela banda de punk rock ${ }^{4}$ Detrito Federal.

Segundo Severiano e Melo (2002, p.200), "O Trem Atrasou é uma das mais antigas canções de protesto da nossa música”. A obra relata em ritmo de samba 
um dos problemas frequentes vividos pela população do Rio de Janeiro nos anos 1940: os constantes atrasos dos trens, que tanto atrapalhavam a vida da população carioca, inclusive a do intérprete da canção, que "teve várias vezes que recorrer a memorandos da Central para justificar atrasos de chegada ao colégio" (Severiano; Melo, 2002, p.200).

Com melodia soturna e letra pessimista, Roda viva dá o clima do fechamento do regime militar em processo já no ano de 1967. A canção, defendida por Chico Buarque no III Festival de Música Popular Brasileira da TV Record, foi tema-título de uma peça montada por José Celso Martinez Corrêa (encenada em 1968) que falava da carreira de um artista criado e triturado pela mídia. A maneira ousada como a peça foi montada gerou uma reação violenta de grupos de extrema-direita ligados ao governo militar, que agrediram os atores da peça nas cidades de São Paulo e Porto Alegre. Talvez a intenção de Chico Buarque não fosse diretamente criticar a ditadura civil-militar - a inspiração para a canção teria surgido por conta da vida desgastante imposta pela maratona de shows do artista nos meses anteriores à apresentação no festival -, mas sem sombra de dúvida a recepção à obra agiu nesse sentido, tanto por conta de quem estava contra o regime da época quanto por quem estava a favor.

A canção Desempregado é uma composição da formação original da banda Detrito Federal. No mais puro estilo hardcore punk, os integrantes da banda berram na letra da canção as desventuras e a revolta de um indivíduo que, sem emprego, não tem condições de saldar suas contas de água, gás ou telefone, pagar pelo transporte coletivo ou mesmo comprar a própria comida. A Detrito Federal surgiu em um contexto de explosão do rock brasiliense na década de 1980, num movimento em que se destacaram grupos como Legião Urbana, Plebe Rude e Capital Inicial.

Problemas para pegar o trem, críticas à ditadura civil-militar ou revolta contra o desemprego, fruto da chamada "década perdida", ocorrida no Brasil nos anos 1980: são todos elementos inspiradores para canções de protesto, com temas diferentes, em contextos históricos diferentes, utilizando-se de estilos musicais variados, alinhados com o contexto cultural da época em que as obras foram compostas.

A proposta deste bloco é salientar aos alunos que o protesto na canção não é exclusividade de uma época; ele aparece ao longo do tempo de forma diferenciada, mas de maneira geral é uma temática muito presente na canção 
brasileira. Um exercício interessante é agregar ao trabalho com canções de protesto do passado alguma obra atual trazida pelos alunos, traçando paralelos em relação ao foco do protesto e a como se dá essa contestação nas diferentes canções, analisando também elementos como o contexto histórico da produção, os ritmos e/ou estilos das canções ou quem está envolvido na sua produção.

O quarto e último bloco tem como objetivo analisar de que forma o contexto histórico pode exercer influência em diferentes versões de uma mesma canção, mesmo que esses registros tenham ocorrido em um curto período.

A primeira obra analisada neste bloco é Outra vez, de Vinicius de Moraes e Antônio Carlos Jobim. Foi gravada na sua primeira versão na forma de um samba-canção, ${ }^{5}$ subgênero do samba muito popular no Brasil na primeira metade do século XX. Surgiu em 1954, cantada por Dick Farney, pianista e cantor de muito sucesso nas décadas de 1940 e 1950, com interpretação que reforçava as características da chamada "dor de cotovelo" na obra: solidão, tristeza, desilusão com o amor perdido. É importante salientar que, ainda que o samba-canção tenha surgido na década de 1920, ele sofre após o fim da Segunda Guerra Mundial uma forte influência do bolero, ritmo de origem cubana que também tem na tristeza uma das suas mais significativas características. Como afirma André Diniz, "O pós-guerra foi marcado por um clima depressivo nas artes; em todo o mundo, predominava um sentimento de melancolia e luto pela perda abrupta de milhões de vidas. Nesse contexto, o samba ganha a roupagem de samba-canção, com letras que falam de desamores e infortúnios" (Diniz, 2006, p.130).

Em uma segunda versão, Outra vez é interpretada pela cantora Elizeth Cardoso. O registro é de 1958, fazendo parte do disco "Canção do Amor Demais". Obviamente com a mesma letra, a obra ganha outro clima com o acompanhamento do músico e cantor João Gilberto ao violão, introduzindo o seu estilo bossa-novista ao instrumento, com um andamento bem diferente do bolero, como lembra Rui Castro, "atrasando e adiantando o ritmo de acordo com o que achava que a letra pedia" (Castro, 1990, p.177). Essas mudanças no segundo registro da canção, em comparação com a gravação original, acabam tendo reflexos na interpretação de Elizeth Cardoso, dando características menos melancólicas para a obra. 
Em uma terceira versão, gravada em 1960, Outra vez aparece com João Gilberto tanto na voz quanto no violão, em registro presente na última faixa do disco "O Amor, o Sorriso e a Flor", segundo LP do artista. Se compararmos com a primeira versão, a canção parece outra obra, por conta das significativas diferenças do arranjo, tanto na música quanto na interpretação do cantor. $\mathrm{O}$ clima triste da intepretação de Dick Farney dá lugar ao estilo leve dos novos arranjos compostos por João Gilberto, fazendo parecer que a perda do amor presente na letra não é motivo para uma tristeza tão grande. A virada da década de 1950 para a de 1960 marca o surgimento e afirmação da bossa nova, levando o samba-canção a perder o prestígio que tinha até então na música brasileira.

As alterações apresentadas nas diferentes versões citadas se fazem notar no arranjo da música, desde o acompanhamento de uma orquestra a Dick Farney, em um samba-canção de andamento moderado, até o violão e a voz de João Gilberto, que alternam constantemente o ritmo da canção, dando roupagem de bossa nova à obra. Apresentam-se também na performance dos intérpretes, na voz tristonha de Dick Farney, na tentativa de Elizeth Cardoso de acompanhar o ritmo de João Gilberto ao violão, ou na sintonia entre voz e violão da versão gravada por ele.

De acordo com Napolitano,

a performance ou ato performático configura um processo social (e histórico) que é fundamental para a realização da obra musical, seja uma sinfonia erudita ou uma canção popular. No segundo caso, a performance tem um campo de liberdade e criação ainda maior em relação às prescrições do compositor ou à gravação original, geralmente tida como paradigmática no caso das canções de sucesso. (Napolitano, 2002, p.86-87)

Nesse processo de transformação, é extremamente importante considerar os elementos históricos do período aqui tratado e como eles se refletem no estilo e nos ritmos das canções. Conforme Napolitano, em outra obra,

O Brasil da década de 1950 experimentava um período democrático, com o crescimento da participação da sociedade civil na cena política, não apenas sob a égide da política de massas conduzida pelo Partido Trabalhista Brasileiro (PTB), mas também sob o signo das lutas operárias e camponesas, com forte presença do então Partido Comunista (PCB). Culturalmente, aquela década pode ser vista 
como uma conjuntura de encontro de várias temporalidades históricas, na qual um Brasil arcaico, provinciano e tradicional era confrontado pelo impacto da modernização capitalista, trazendo um novo ciclo de industrialização e urbanização, sobretudo após 1956, com a posse de JK. (Napolitano, 2007, p.587-588)

Uma população jovem, de classe média, que tinha a Zona Sul do Rio de Janeiro como lar e que vivia num país que passava por uma intensa transformação, não se vê alinhada a um estilo de música que tinha no sofrimento e na solidão os seus temas principais. Essa nova geração, de Carlos Lyra, Roberto Menescal, Nara Leão e Ronaldo Bôscoli, encontrou um grupo de artistas que participava da transição do samba-canção “abolerado" para uma versão menos dramática desse estilo musical - com transformações na música, nas letras, no arranjo, na instrumentação -, da qual faziam parte compositores e intérpretes como Antônio Carlos Jobim, Aloysio de Oliveira, Tito Madi, Dolores Duran, Johnny Alf, Lúcio Alves e Dick Farney. Jovens de Copacabana e de bairros próximos vão gradativamente trocar a sanfona pelo violão. Essa classe média vai ser de certa forma prioritariamente a produtora e a consumidora desse novo estilo musical.

No contexto de sala de aula, em atividades nas quais se trabalham diferentes versões de uma mesma obra, dispomos de uma quantidade significativa de possibilidades. Por exemplo, a canção Pra não dizer que não falei de flores (Caminhando), de Geraldo Vandré, tem duas versões que ficaram bastante famosas. A original foi apresentada pelo próprio autor pela primeira vez no III Festival Internacional da Canção, promovido no Rio de Janeiro pela Rede Globo em 1968, enquanto uma segunda versão foi gravada pela cantora Simone, no disco “Ao vivo no Canecão", em 1980. Os diferentes registros foram feitos em conjunturas históricas bem interessantes. O lançamento da canção por Vandré ocorre em um momento no qual o regime militar que controlava o Brasil se fechava, pouco antes da decretação do AI-5. Uma das mais características canções de protesto da década de 1960, Pra não dizer que não falei de flores (Caminhando) foi composta com estrutura musical simples, baseada em dois acordes, tendo seu foco principal na letra, de teor fortemente político. Um dos maiores sucessos da carreira de Geraldo Vandré, com muito destaque na época em que foi lançada, a obra gerou perseguição sistemática ao autor, patrocinada pelo governo brasileiro da época, que considerava a 
composição uma afronta ao regime constituído. Como reflexo dessa perseguição, ainda em 1968, o artista fugiria para o Paraguai em busca de exílio, estabelecendo-se posteriormente no Chile, enquanto a canção seria censurada e proibida por mais de 10 anos.

A versão gravada ao vivo por Simone surge em um momento no qual o Brasil esboçava um processo de redemocratização, com destaque à campanha pela anistia política, ao movimento contra a carestia e à reorganização do sindicalismo brasileiro, responsável pelas ondas de greves promovidas por vários setores de trabalhadores, como metalúrgicos, bancários e professores públicos. Iniciado em 1978, esse processo ganharia mais força na década de 1980. No registro de Simone, o arranjo é quase tão simples quando o da versão original, dando ênfase mais uma vez ao forte discurso antiautoritário presente na letra.

Traçando um paralelo, temos nas duas versões manifestações em defesa da democracia, em momentos históricos nos quais ela se encontrava debilitada pela existência de um regime de exceção. A manutenção do mesmo arranjo age no sentido de retomar a mensagem lançada por Geraldo Vandré pela volta do Estado de direito, golpeado pela ditadura militar iniciada em 1964.

Outra possibilidade interessante dentro dessa mesma proposta pode ser colocada em prática pela elaboração de uma atividade com duas versões da canção 17 légua e meia, de Carlos Barroso e Humberto Teixeira. Na versão original, gravada por Luiz Gonzaga em 1950, a obra é executada como um típico baião, ${ }^{6}$ ritmo que deu ao cantor e compositor nordestino destaque nacional. Já no registro de Gilberto Gil, a gravação é feita com instrumentos elétricos e bateria, lembrando um rock, porém em alguns momentos retoma-se o arranjo original, com a presença das características do baião. Mais uma vez é importante retomar o contexto histórico para melhor compreensão da maneira como as diferentes versões foram gravadas. Na década de 1950, quando foi registrada a primeira versão de 17 légua e meia, o baião era um dos ritmos de maior sucesso da música brasileira, popularizando-se principalmente por conta do protagonismo artístico de Luiz Gonzaga e Humberto Teixeira. A versão gravada por Gilberto Gil quase 20 anos depois é claramente uma criação ligada ao movimento tropicalista, que buscava produzir uma nova sonoridade a partir do casamento do internacional com o regional (na busca de um som universal, como falava o mesmo Gilberto Gil), misturando o tradicional com o 
contemporâneo. Ao mesmo tempo, a versão de 1969 aparece como uma homenagem de Gil às suas origens nordestinas.

Por meio das canções selecionadas neste bloco, é possível trabalhar a relação entre o contexto histórico no qual as versões foram gravadas e as diferenças apresentadas em elementos como o arranjo e performance dos intérpretes. Nessa proposta, excluímos do foco de análise a letra da canção e o apontamos para outros aspectos da obra, que nos oferecem múltiplas possibilidades. No trabalho com os alunos, podemos levantar desde discussões mais básicas, como apontar as semelhanças e diferenças entre os registros apresentados, até reflexões mais elaboradas, como buscar a possível influência das transformações pelas quais passava o Brasil no período e as diferenças encontradas nas versões aqui citadas.

Evidentemente, para que o aluno possa debater esses questionamentos, $\mathrm{o}$ contexto histórico que envolve o período em que as versões aqui apresentadas foram veiculadas deverá ter sido trabalhado e discutido em sala de aula. Nesse sentido, os documentos sonoros apresentados servirão de subsídio para o aprofundamento dessa discussão.

\section{PASSOS POSSÍvEIS PARA UM TRABALHO NO ENSINO BÁSICO}

\section{A PARTIR DO USO DE CANÇÕES COMO FONTE HISTÓRICA}

O foco principal deste artigo foi discutir as possibilidades de trabalho com a canção brasileira nas aulas de História. Com base nessa proposta, foram apresentadas, em quatro blocos compostos por canções selecionadas, sugestões de atividades envolvendo obras musicais que podem ser pensadas e analisadas como fontes históricas para buscarmos e estudarmos informações sobre o passado. As propostas aqui apresentadas foram desenvolvidas em sua grande maioria com alunos de graduação em História. Algumas delas foram expostas em oficinas para professores, e umas poucas em atividades com alunos do ensino fundamental.

Acredito que tais propostas possam ser utilizadas em turmas de ensino básico mediante ajustes ou mesmo na íntegra, dependendo do nível de aprofundamento que esse tipo de trabalho possa vir a ter em uma turma composta por crianças ou adolescentes. Acima de tudo, creio ser importante um processo de preparação dos alunos, que envolva uma troca entre o que eles ouvem e o que o professor pretende trazer para a audição, análise e debate, pois considero 
que quanto mais houver essa troca, mais construtiva pode ser a experiência. $\mathrm{O}$ interessante é abrir espaço para a manifestação do aluno na formulação da proposta que será posta em prática, sem deixar de apresentar aquilo que pode ser novidade para o aluno, como canções, estilos, temas e narrativas que, sendo de outras épocas, talvez ele não conheça, e que podem apresentar informações sobre o passado, enriquecendo o debate em sala de aula.

Penso que para esse tipo de atividade deva haver uma preparação dos alunos, que envolva ações no sentido de sensibilizar e aproximar os participantes da proposta apresentada. Assim, apresento alguns passos que podem ser interessantes para introduzir as atividades com canções nas aulas de História:

- definir o que é uma fonte histórica;

- apresentar as diferentes fontes históricas existentes;

- definir para os alunos o que é uma fonte sonora;

- fazer um apanhado sobre os tipos de música que os alunos ouvem e como elas são ouvidas;

- fazer uma aproximação entre o que os alunos ouvem e algumas canções do passado, focando em temas a serem trabalhados em sala de aula (como, por exemplo, violência, trabalho, desigualdade etc.);

- a partir da aproximação, trabalhar com elementos históricos presentes nas canções;

- avaliar com os alunos de que forma essas canções se constituem como fontes históricas, trazendo consigo elementos do cotidiano, da política, da sociedade, recursos tecnológicos utilizados, além de muitos outros aspectos. Em linhas gerais, avaliar como essas fontes podem estar carregadas de História.

Finalizando, nunca podemos perder de vista que ao trabalharmos a canção brasileira em sala de aula não devemos ter como objetivo o desenvolvimento de uma atividade recreativa, ou mesmo um show de curiosidades (onde o professor apresenta o que lhe parece interessante e o aluno mostra o que ouve no dia a dia). A proposta deve ter como eixo principal a análise de fontes históricas, que não devem ser consideradas como algum tipo de curiosidade sobre o passado ou um fragmento da verdade deixada por nossos ancestrais, mas sim um documento produzido com alguma intencionalidade, passível de análise, crítica e discussão. 


\section{REFERÊNCIAS}

ABUD, Kátia M.; SILVA, André Chaves de M.; ALVES, Ronaldo C. Ensino de História. São Paulo: Cenage Learning, 2010.

BITTENCOURT, Circe Maria F. Ensino de História: fundamentos e métodos. São Paulo: Cortez, 2008.

CASTRO, Ruy. Chega de saudade: história e as histórias da bossa nova. São Paulo: Companhia das Letras, 1990.

. Samba-canção, uísque e Copacabana. In: DUARTE, Paulo S.; NAVES, Santuza C. Do samba-canção à tropicália. Rio de Janeiro: Relume Dumará; Faperj, 2003. p.15-24.

DINIZ, André. Almanaque do Samba: a história do samba, o que ouvir, o que ler, onde curtir. Rio de Janeiro: Jorge Zahar, 2006.

DOURADO, Henrique A. Dicionário de termos e expressões da música. São Paulo: Ed. 34, 2004.

DUQUE, Luís Guilherme R. A canção brasileira na sala de aula: possibilidades didático-pedagógicas. Aedos, Porto Alegre: Revista do Corpo Discente do Programa de Pós-Graduação em História da UFRGS, v.4, n.11, p.7-27, 2012. Disponível em: http://seer.ufrgs.br/aedos/article/view/30639.

. Quinze canções para compreender a ditadura militar brasileira: a música como prática pedagógica em História nos ensinos básico e superior. In: BARROSO, Vera Lucia M. [et al.] Ensino de História: desafios contemporâneos. Porto Alegre: Est Editora; Anpuh/RS, 2010. p.267-278.

FAUSTO, Boris. Historia do Brasil. São Paulo: Edusp, 2000.

GUIMARÃES, Selva. Didática e Prática de Ensino de História: experiências, reflexões e aprendizados. Campinas: Papirus, 2003.

HERMETO, Miriam. Canção popular brasileira e ensino de história: palavras, sons e tantos sentidos. Belo Horizonte: Autêntica, 2012.

LE GOFF, Jacques. A História Nova. São Paulo: Martins Fontes, 2005.

LOPES, Ney. Sambeabá: o samba que não se aprende na escola. Rio de Janeiro: Casa da Palavra; Folha Seca, 2003.

MATTOS, Maria Izilda de. Antonio Maria: boêmia, música e crônicas. In: DUARTE, Paulo S.; NAVES, Santuza C. Do samba-canção à tropicália. Rio de Janeiro: Relume Dumará; Faperj, 2003. p.25-45.

MELlO, Zuza H. de. A Era dos Festivais. São Paulo: Ed. 34, 2003.

NAPOLITANO, Marcos. Forjando a revolução, remodelando o mercado: a arte engajada no Brasil (1956-1969). In: FERREIRA, Jorge; REIS FILHO, Daniel A. (Org.) 
As esquerdas no Brasil. v.2: Nacionalismo e reformismo radical. Rio de Janeiro: Civilização Brasileira, 2007. p.585-617.

NAPOLITANO, Marcos. Música \& História. Belo Horizonte: Autêntica, 2002.

PARANHOS, Adalberto. Ciladas da canção: usos da música na prática educativa. Disponível em: www2.faced.ufu.br/colubhe06/anais/arquivos/442AdalbertoParanhos. pdf; Acesso em: 22 ago. 2016.

PEREIRA, Nilton M.; SEFFNER, Fernando. O que pode o ensino de História? Sobre o uso de fontes na sala de aula. Anos 90, Revista do Programa de Pós-Graduação em História da UFRGS, v.15, n.28, p.113-128, dez. 2008. Disponível em: http://seer. ufrgs.br/anos90/article/view/7961/4750.

RIDENTI, Marcelo. Em busca do povo brasileiro. Rio de Janeiro: Record, 2000.

SEVERIANO, Jairo; MELLO, Zuza H. de. A canção no tempo: 85 anos de músicas brasileiras. vol.1: 1901-1957. São Paulo: Ed. 34, 2002.

A canção no tempo: 85 anos de músicas brasileiras, vol.2: 19581985. São Paulo: Ed. 34, 2002.

SILVA, Francisco Carlos T. da (Org.) Enciclopédia de guerras e revoluções do século $X X$ : as grandes transformações do mundo contemporâneo. Rio de Janeiro: Elsevier, 2004.

\section{NOTAS}

${ }^{1}$ A chamada canção de protesto, também conhecida como música de protesto ou canção engajada, surge do Brasil nos anos 1960 e ganha força em meados da mesma década, após o golpe civil-militar de 1964. A canção de protesto não expressava a sua insatisfação político-social só nas letras; as obras carregavam fortes elementos de cultura regional, ou popular, naquilo que parecia ser uma busca da identidade nacional por meio da canção. Para um aprofundamento sobre o tema, sugiro RIDENTI (2000).

${ }^{2} \mathrm{O}$ rap é uma abreviatura em inglês de rythm and poetry (ritmo e poesia). Segundo DOURADO (2004, p.272), "gênero de música quase declamada de negros norte-americanos, surgiu no final do século XX com forte conotação de protesto e contestação social”.

${ }^{3} \mathrm{O}$ xote, ou xótis, teve origem na Europa como uma dança de salão, em meados do século XIX. Após chegar ao Brasil, adquiriu perfis diversos em diferentes regiões do país. Tornou-se uma dança típica do Nordeste, muito executada no forró. Para mais informações, ver DOURADO (2004).

${ }^{4}$ Conforme SILVA (2004, p.726-727), "é difícil estabelecer uma data exata para o início do punk rock. Sabe-se que foi a partir da segunda metade da década de 1970 que ganhou o mundo por intermédio de bandas como Ramones (1976, EUA) e Sex Pistols (1977, Inglaterra) ... A partir do tema punk 'do it yourself', milhares de jovens pelo mundo inteiro 
criaram as suas próprias bandas, seguindo a batida acelerada, muita distorção nas guitarras e fazendo letras contra o establishment. Neste sentido, pode-se dizer que o punk democratizou o rock: muitos jovens passaram a pensar que não era mais preciso ser um 'virtuose' para se ter uma banda”.

${ }^{5}$ Sobre as características do samba-canção, discorre LOPES (2003, p.17): é “(um) samba de andamento lento, de melodia romântica e letra sentimental".

${ }^{6} \mathrm{O}$ baião é um gênero de música e dança típico do Nordeste brasileiro. Tem como característica principal o início das frases após o tempo forte. Geralmente, um conjunto clássico de baião é composto por sanfona, triângulo e zabumba. É interessante notar que na versão original de 17 légua e meia esses instrumentos, acompanhados pelo cavaquinho, são "convocados” por Luiz Gonzaga no início da canção. Sobre o baião, ver DOURADO (2004).

Artigo recebido em 16 de novembro de 2016. Aprovado em 7 de fevereiro de 2017. 